\title{
Challenges of teleworking during the COVID-19 pandemic
}

\section{Изазови рада на даљину у току COVID-19}

\section{Mile Vasic}

European Marketing and Management Association, Banja Luka, Bosnia and Herzegovina, mile.vasic@eummas.net

Abstract: The purpose of this paper is to determine how companies in the South-East European countries responded to the crisis caused by COVID-19 pandemic and work from home challenges, and what could be done in the future to overcome obstacles of working remotely. Forced by the pandemic to change the working style, companies needed to find the best possible solutions to ensure a sufficient level of working activities. Since such a challenge was faced for the first time in modern human history, not many companies were prepared for it. A quantitative approach was taken, using an online survey for the research. The findings are discussed and presented with reference to the relevant theories. The study reveals and points out the main concerns and problems related to working separately from the rest of the organization. The study analyzes how certain factors of working remotely such as lack of traditional leadership, physical workspace, isolation, etc. affected the life and work of employees during the crisis. The study is novel as these were the circumstances we had not faced before. The paper contributes to a better understanding of all of the aspects of teleworking, with an emphasis on social isolation and working under lockdown.

Keywords: working remotely, leadership, social isolation, work-life conflict JEL classification: 015, D23, J81

Сажетак: Сврха овог рада је да се утврди како су компаније у државама југоисточне Европе одговориле на кризу проузроковану пандемијом COVID-19 као и на изазове рада од куће, те шта би се могло учинити у будућности како би се превазишле препреке рада на даљину. Присиљени пандемијом да промјене стил рада, компаније су требале пронаћи најбоља могућа рјешења како би обезбиједиле задовољавајући ниво пословних активности. Пошто се са оваквим изазовом сусрећу по први пут у модерној историји човјечанства, мало компанија је била спремна за њега. Квантитативни приступ је одабран, кроз употребу online анкете за истраживање. Резултати су представљени и поткрепљени са референцама на релевантне теорије. Студија открива и указује на главне изазове и проблеме везане за рад који се одвија одвојено од остатка организације. Студија анализира како одређени фактори рада на даљину као што је недостатак традиционалног лидерства, радно мјесто у физичком смислу, изолација итд. утичу на живот и рад запослених за вријеме кризе. Тренутна студија је новина пошто се ради о условима са којима се до сада нисмо суочавали. Рад доприноси бољем разумјевању свих аспеката рада на даљину, са посебним нагласком на друштвену изолованост и рад у условима забране кретања.

Кључне речи: рад на даљину, лидерство, друштвена изолација, конфликт пословног и приватног живота JEЛ класификација: 015, D23, J81 


\section{Introduction}

Millions of workers around the world are going through the difficult time of redefining the way they work. Since the outbreak of the COVID-19 pandemic, the work environment has changed overnight and everybody needed to adopt suddenly and quickly. The challenges of managing personal safety, family matters, and work-related duties do not seem to be simple. On the contrary, from day to day the workers face new challenges and problems. How they tackle these challenges will have profound consequences on their productivity and company success. The purpose of this paper is to specificly determine how companies in the South-East European countries responded to the crisis caused by COVID-19 pandemic and work from home challenges, and what could be done in the future to overcome obstacles of working remotely.

What have been the major issues and problems? At first, a large number of employees did not have proper equipment and resources to work from home. Since most of the people remained at home, Internet usage rose sharply. With the rise of social distancing, people were seeking out new ways to connect and to keep in touch with family and friends, mostly through video chat. The others tried to make good use of time by watching movies online, downloading tons of eBooks and materials, playing games, etc. All of that slowed down the Internet connections and caused delays for those who needed the Internet for work. Besides the troubles with ensuring a stable and fast internet connection, many employees faced the other technology hiccups such as inadequate hardware or luck of certain software. Some workers did not have sufficient technical skills, the others were confused and could not communicate with the rest of the team and organization properly. Not being able to receive clear face-to-face instructions, e-leadership for some workers was a major source of stress and insecurity. At the same time business leaders also face problems in redefining what supervising employees mean in the context of telework. How to supervise? How to motivate? What is too much or too little?

Although it seemed interesting at the beginning to work and at the same time stay in a pajama for the whole day at home, the work-life conflict became one of the major obstacles. How to explain a three-year-old that mother now works from home? How to explain that a kitchen is now an office? How to mentally escape from the house?

Balancing work and life in regular situations is hard, not to mention situations when everybody is forced to stay indoors. Feeling of being locked down and trapped influences people's moods and cause depression, intellectual disabilities, neurological disorders, and mental illness. On the other side, people who live alone may feel lonely and lack human interactions. These people usually face the other kind of problems such as overworking. When someone's work and personal life are under the same roof, it may be hard to draw a line between them and set borders.

With the outbreak of COVID-19 and the need to switch from office to remote work, we found out that many workers had never been trained to telework so that improvisation was the only option they had. This paper reveals how companies operating in SEE responded to the COVID-19 crisis and work from home challenges and what is to be done 
in the future to overcome obstacles of teleworking. The study explored problems of working remotely under lockdown such as loyalty, motivation, proper leadership, workload, work-life balance/conflict, job performance measurement, appraisal, coping with stress, job insecurity, (virtual) team working, lack of skills and resources, etc. The findings will contribute to the advancement of knowledge on teleworking and managing human resources remotely.

\section{Literature review}

It is in human nature to support each other in case of danger. It is said that humans are born with an urge to help. It is also known that in case of a collective danger, people start relying more on each other and offer support more than usual even to a stranger. The reason is always the same - survival. To survive, people must be protective, reliable, attentive, and considerate. At work, people start caring more about each other, about their colleagues and coworkers, and finally about their company. The team spirit and loyalty to the company suddenly peak. In those times, we become more proud of being a part of society, a part of the company.

Loyalty has always been important to both, the workers and the organizations. It gives people a feeling of security and calm. An employee who is proud of the organization she/he works for, ultimately is more loyal and devoted to that organization knowing that she/he is a part of something bigger than herself/himself and that her/his contribution towards organizational success counts (Graham \& Cascio, 2018, p. 366). The fear of personal loss becomes stronger and employees worry more not only about themselves but about the future of the company and society as well. Although wishing to support the company to the best of their abilities, many workers find it challenging to adopt some changes in the work environment - to work in an improvised home office far from the coworkers, i.e. to telework.

Teleworking is not a new thing and has been adopted worldwide by many companies but not in the high extent. Telework is mainly employed in education and health, information and communication, and in large firms (Pigini \& Staffolani, 2019). Thanks to the new technologies employees can work from any location and not be required to physically be present in the traditional office. Terms virtual work, remote working, teleworking, telecommuting, etc. are used for work performed by employees outside the traditional office using information and telecommunication technologies. Such work is becoming more and more popular. However, still many managers believe that teleworkers are not as productive as the workers in traditional offices. On the other side, a number of studies suggest that teleworkers can be more productive because they can work during their most productive time and be less distracted by co-workers (Nakrošienè et al., 2019, p. 88).

The average number of teleworkers in the European Union (EU) Member States is considerably lower, amounting to 17 percent in 2015 and ranges from 7 percent in Italy to 37 percent in Denmark (Nakrošienè et al., 2019, p. 88). According to Nakrošienè et al., (2019) in Central and Eastern European countries, the corresponding telework figure is lower than the EU average at 14 percent (Nakrošienè et al., 2019, p. 88). The latest statistics 
provided by GlobalWorkplaceAnalytics.com (2018) shows 4.3 million employees (3.2 percent of the workforce) work at least half their hours from home. Since 2005, the number of telecommuters has grown by 140 percent, nearly 10 times faster than the rest of the workforce (Wang et al., 2020, p. 609-610). According to the latest statistics of EUROSTAT (2020) in 2019, 5.4\% of employed persons in the European Union (EU) who were aged 1564 , usually worked from home and the share did not change throughout the last decade, while the share of those who sometimes worked from home has been rising from $6.0 \%$ in 2009 to $9.0 \%$ in 2019 . The same source indicates that the Netherlands and Finland topped the list with $14.1 \%$ of employed people usually working from home in 2019 , followed by Luxembourg (11.6\%) and Austria (9.9\%) while the lowest rates of home-workers were reported in Bulgaria (0.5\%), Romania (0.8\%), Hungary (1.2\%), Cyprus (1.3\%), Croatia and Greece (both 1.9\%). Four of the five SEE countries that are EU member states are among the EU countries that have the lowest teleworking rates (Bulgaria, Romania, Croatia, and Greece).

A better measure of human capital is task performance, which encompasses realized human capital within an organization (Zatzick, et al. 2015:878). Several studies have investigated the effects of telework on family-work relations, and on work performance, but in spite of this, the effects of telework are not clear, given that results of the different studies are contradictory (Solís, 2017, p. 21). However, some studies indicate that the suitability of the working place at home and decreased time for communication with coworkers are the most important telework factors impacting different telework outcomes (Nakrošienè et al., 2019, p. 94). It would be easier to accept teleworking under normal circumstances. Also, under normal circumstances, social isolation would not affect us the same way it affects us now. Reduced amount of physical contact and interaction between workers and supervisors make individuals feel isolated and distant from the social life of the firm (Kossek et al., 2015). The impact of social/physical distancing on family-work relations, work performance, productivity, and job satisfaction would significantly differ. The same study suggests that the reduced time for communication with co-workers increases the productivity of teleworkers and can be seen as a contra argument to the social isolation of teleworkers (Nakrošienè et al., 2019, p. 97).

However, some managers still tend to believe that teleworking would not be acceptable for their company since physical isolation could lead to psychological isolation. What is psychological isolation? Psychological isolation refers to feelings of emotional unfulfillment when one lacks meaningful connections, support, and interactions with others, while physical isolation refers to physical separation from others (Wang et al., 2020, p. 609). At relatively high levels of telecommuting, a significant loss of face time and more social isolation are likely to increasingly offset the individual's ability to satisfy both individual and organizational needs, negatively affecting job satisfaction (Golden \& Veiga, 2006 , p. 303). The same study suggests that job satisfaction initially increases as the extent of telecommuting rises; however, at higher levels of telecommuting, it starts to level off and decrease slightly and essentially plateaus; although this suggests that the impact of telecommuting on job satisfaction is more complex than previously thought, it also suggests 
that gains in job satisfaction at lower levels of telecommuting are relatively substantial compared with those at higher levels (Golden \& Veiga, 2006, p. 312-313).

But how is it possible not to be satisfied when you have to work from home? Isn't it an advantage to stay home and do your job instead of commuting? Isn't it a good way to balance work and life, to spend more time with the family, to be home when they need you? In fact, yes. Many studies suggest that. Gajendran \& Harrison (2007) conducted a research and their results suggest that telecommuting is likely more good than bad for individuals and that it has a clear upside: small but favorable effects on perceived autonomy, workfamily conflict, job satisfaction, performance, turnover intent, and stress. They argue that contrary to expectations in both academic and practitioner literature, telecommuting also has no straightforward, damaging effects on the quality of workplace relationships or perceived career prospects.

So, as we can see, many analyses and studies, many different opinions and findings. The physical isolation, physical separation or social distancing from coworkers may or may not have, as we can see, a positive impact on family-work relations, work performance, productivity, and job satisfaction but the lack of traditional face-to-face leadership and working with an e-leader may be challenging for most workers. Also, managers can find it hard to communicate and delegate properly. A very significant function of leadership is effective communication with followers, constituents, partners, and external publics (Liu et al., 2018, p. 827). Leader communication is not only about knowledge and cognition, but also about feelings and emotion, awareness must take into account the affective aspects of virtual communication, not only by the richness of the medium and tool but also its ability to satisfy recipients' desire for speed, customization, reminders, etc. (Liu et al., 2018, p. 837).

Followers in many cases wish to have precisely delegated tasks. They feel safe when they seek and get feedback, share and receive information, and ask and offer help. They feel and they know that their efforts and work performance must be noticed, measured, and appraised. A better measure of human capital is task performance, which encompasses realized human capital within an organization (Zatzick et al., 2015, p. 878). Inadequate measuring of work performance and lack of information imposes additional stress on workers. Lajšić (2019) argues that in modern human resource management, it is necessary to emphasize the importance of measuring performance. It is even more important now to give feedback as well as an appreciation for a well-done job than in regular circumstances. Motivation must not be neglected. In traditional organizations, supervisors are not only tasked with ensuring high-quality performance, but they are also meant to motivate workers and to provide social support (Jabagi et al., 2019, p. 194).

Motivation is crucial in times of sudden changes. Organizations need to change constantly and adopt new work style and habits to stay competitive. Nowadays, both the organizations and their workers need to accept the reality of remote working being aware that many companies will not succeed and survive on the market. At the employee level, however, changes oftentimes evoke feelings of job insecurity (De Cuyper et al., 2020, p. 221). However, the feeling of insecurity usually has a positive impact on work performance 
although workers may feel that workload affects their private life and health as well. Loyal workers will work even harder and will spend far more time "at work" than usual. When one becomes unaware of time and usual working hours vanishes, private life and family suffer. Working too much and too long can help the company at one point in time, but in the long run, it may ruin an individual's health and life. Therefore, leaders should carefully assign tasks bearing in mind the optimum workload and the employees' well-being. Workload refers to the quantity and difficulty of work. Most often employees feel overloaded when the quantity of work exceeds the regular working schedule and amount of work. However, sometimes it is simply difficult to stop working. Communication with superiors and coworkers require often exchange of information. In distance working, it means tons of emails and other textual messages that create communication overload. Communication overload occurs when a third party solicits the attention of the knowledge worker through such means as email, instant messaging, or mobile devices that cause excessive interruptions in his or her job to the point the knowledge worker becomes less productive (Karr-Wisniewski \& Lu, 2010, p. 1063). E-mail overload can keep a person stuck in front of a computer for hours not even being aware of it.

The literature on e-mail load suggests that the extent to which individuals think email is helpful or desirable influences their e-mail use (Stich et al., 2019, p. 433). With the bulk of e-mails, we simply become overloaded with information. Information overload occurs when the volume of the information supply exceeds the limited human information processing capacity and dysfunctional effects such as stress and confusion are the results (Eppler \& Mengis, 2004, p. 328). In theory, that kind of stress is known as role stress since it is related to the inability to perform certain tasks and roles. Role stress occurs when an employee tries to fulfill the behaviors that are expected when completing the role (Delpechitre et al., 2019, p. 321). An employee under stress cannot be productive and the level of satisfaction is significantly low. Moreover, the gap between life and work is wider.

How does the increased workload impact work performance? The relationship between workload and performance is not a straightforward one, as workload should not impede performance as long as it is not too high (Pindek et al., 2019, p. 82). However, when it is too high it impedes not only the performance, motivation but the private life as well. When working remotely, the employee has to choose between two important roles being a parent or being a company soldier. Work-family conflict represents a role imbalance between those two responsibilities. Companies are expected to pay more attention to their employees' wellbeing by increasing their satisfaction so that the employees behave appropriately for the interests of the companies in the long term. Therefore, companies should prevent work-family conflict in their employees. The impacts of work-family conflict in employees are work stress, turnover intention, and maybe audit quality reduction behavior (Amiruddin, 2019, p. 438). All of these will impact both the individuals and the organization.

To cope successfully with teleworking hiccups and challenges companies should be able to anticipate certain obstacles that might influence the life and work of its employees. A proper teleworking program may be of help. To make them, organizations should be aware of critical success factors in developing and implementing such programs. As 
Kowalski and Swanson suggest, those critical success factors are support, communication, and trust (Kowalski \& Swanson, 2005). The company has to provide all the necessary resources critical for successful teleworking. Before all, it should provide proper technology and tools to all teleworkers and training for both teleworkers and their managers. Some workers may find it challenging to cope with new technologies and it can impact the level of satisfaction and productivity. Suh \& Lee (2017) examine how technology and job characteristics jointly induce teleworkers' technostress (work stress caused by information technologies), how technostress influences teleworkers' job satisfaction, and how the patterns of the technostress that teleworkers experience vary depending on their intensity of teleworking and found out that technology-induced stressors (i.e. work overload, invasion of privacy, and role ambiguity) lead to greater strain, which in turn reduces teleworkers' job satisfaction; it is a well-known fact that a high level of work satisfaction can increase workers' productivity, whereas a low level of work satisfaction increases employee turnover; therefore, the study's results imply that the technostress perceived by teleworkers directly influences the productivity of individuals and organizations and the results demonstrate that the faster the pace of the IT changes, the higher the level of work overload and role ambiguity perceived by workers (Suh \& Lee, 2017).

Another study that is in favor of the importance of providing company support to the workers in the study conducted by Stich et al. (2018) who suggest that organizations should provide training to employees since not everyone likes technology or can use it well or effectively. New technologies associated with digital transformation promise to improve business performance but require competencies that need to be improved (Erceg \& Zoranović, 2020, p. 53). Besides avoiding IT obstacles, a comprehensive teleworking program should be developed describing in detail all processes, procedures, and policies. Special attention must be drawn to the family issues and both managers and workers should be able to draw a line between private life and work to maintain a healthy environment and provide well-being to all. Training must not be neglected and should include the development of various skills needed for teleworking, such as the use of technologies, communication skills, delegating, virtual teamwork, etc. We have already discussed the importance of good communication and here we just have to point out that there is no trust if we miscommunicate. As with support and communication, trust is necessary at all levels of the teleworking organization (Kowalski \& Swanson, 2005, p. 243). Another study also points out the importance of trust in teleworking suggesting that successful virtual workers are able to develop trust early on, enhance others' trust in their own ability, and engender increased relational trust from others (Makarius \& Larson, 2017, p. 161).

\section{Research questions}

According to the above said, the following research questions were formulated:

RQ1. If employees are worried about the impact of coronavirus on them and their organizations, do they demonstrate a high level of loyalty?

RQ2. If workers were unprepared for the pandemic situation and found it difficult to 
work remotely, do they prefer the traditional way of working compared to teleworking?

RQ3. What is the role of proper leadership and support for teleworking?

RQ4. Does teleworking under lockdown differ to a great extent from traditional teleworking?

\section{Methodology}

The research questions were set and an online survey was made. The survey was delivered through LinkedIn (https://www.linkedin.com), an employment-oriented online service that operates via websites and mobile apps used for professional networking, using the survey created through the service offered by SurveyMonkey (www.surveymonkey.com). SurveyMonkey was used because of the features that assisted in the analysis of the data collected and encryption options that ensure the confidentiality of the data. The author's network of more than 12.000 connections, as well as four other LinkedIn groups of about 20.000 professionals working in companies in SEE countries, were used and the relevant URL with the survey was shared with the network both in private messages and by posting it on the walls.

The research was conducted between the $10^{\text {th }}$ of April and $10^{\text {th }}$ of May 2020, targeting individuals from South-East Europe (Albania, Bosnia and Herzegovina, Bulgaria, Croatia, Greece, Moldova, Montenegro, North Macedonia, Romania, Serbia, Slovenia, and Turkey), and 2,863 professionals $(\approx 8.9 \%)$ responded to the questionnaire. A ten-item questionnaire was adapted and different types of survey questions were used. A list with fifty industries was offered in the survey and only nine (sales, banking, education, HR, pharmaceuticals, advertising, consulting, government, and IT) that were chosen most are presented in the paper. The profile of respondents (gender, age, geographical distribution, industries, and company size) is given in Table 1 below, and Survey questions and responses are presented in Table 2.

\section{Findings and discussion}

As mentioned above a demographic data was collected to illustrate the profile of respondents that took part in this survey (Table 1). The respondents were from 12 SEE countries: Albania, Bosnia and Herzegovina, Bulgaria, Croatia, Greece, Moldova, Montenegro, North Macedonia, Romania, Serbia, Slovenia, and Turkey. Five of them are EU member states: Bulgaria, Croatia, Greece, Romania, and Slovenia. Out of 2,863 respondents, 53.34\% were female workers, and more than 60\% were aged 31-55. The highest number of respondents were employed in sales, banking, education, HR, pharmaceuticals, advertising, consulting, government, and IT sectors. Only 9.74\% worked in large-sized companies (by the number of employees). It is understandable since most of the countries have gone through the transformation of their economies and process of privatization in the past three decades and the large business systems, that had been the backbone of their national economies, no longer exist. Also, small and medium-sized enterprises (all enterprises with less than 250 employees) are now seen as the backbone of 
the European economy. In developed EU countries, it can be applicable since they still have large business systems that serve as a port for small boats i.e. small and medium-sized enterprises.

Table 1: The profile of respondents (n/\%)

\begin{tabular}{|c|c|c|c|}
\hline \multicolumn{2}{|c|}{ The profile of respondents $(\mathrm{N}=2863)$} & \multirow[t]{2}{*}{ Count } & \multirow[t]{2}{*}{ Percent } \\
\hline Gender & & & \\
\hline & Female & 1527 & $53.34 \%$ \\
\hline & Male & 1336 & $46.66 \%$ \\
\hline \multicolumn{4}{|l|}{ Age } \\
\hline & $18-30$ & 796 & $27.80 \%$ \\
\hline & $31-45$ & 1171 & $40.91 \%$ \\
\hline & $46-55$ & 569 & $19.87 \%$ \\
\hline & $56-65$ & 327 & $11.42 \%$ \\
\hline \multicolumn{4}{|c|}{ Geographical distribution } \\
\hline & Albania & 64 & $2.23 \%$ \\
\hline & Bosnia and Herzegovina & 131 & $4.58 \%$ \\
\hline & Bulgaria & 270 & $9.43 \%$ \\
\hline & Croatia & 174 & $6.08 \%$ \\
\hline & Greece & 338 & $11.81 \%$ \\
\hline & Moldova & 67 & $2.34 \%$ \\
\hline & Montenegro & 41 & $1.43 \%$ \\
\hline & North Macedonia & 89 & $3.10 \%$ \\
\hline & Romania & 563 & $19.66 \%$ \\
\hline & Serbia & 391 & $13.66 \%$ \\
\hline & Slovenia & 121 & $4.23 \%$ \\
\hline & Turkey & 614 & $21.45 \%$ \\
\hline \multicolumn{4}{|c|}{ Industries } \\
\hline & Sales & 272 & $9.50 \%$ \\
\hline & Banking & 246 & $8.60 \%$ \\
\hline & Education & 333 & $11.63 \%$ \\
\hline & HR & 578 & $20.19 \%$ \\
\hline & Pharmaceuticals & 167 & $5.83 \%$ \\
\hline & Advertising & 158 & $5.51 \%$ \\
\hline & Consulting & 271 & $9.47 \%$ \\
\hline & Government & 138 & $4.82 \%$ \\
\hline & IT & 344 & $12.02 \%$ \\
\hline & Other & 356 & $12.43 \%$ \\
\hline \multicolumn{4}{|c|}{ Company size } \\
\hline & $\operatorname{Micro}(<10)$ & 1124 & $39.26 \%$ \\
\hline & Small $(<50)$ & 1023 & $35.73 \%$ \\
\hline & Medium $(<250)$ & 477 & $16.66 \%$ \\
\hline & Large $(>250)$ & 239 & $8.35 \%$ \\
\hline
\end{tabular}

Source: the author's research

RQ1. If employees are worried about the impact of coronavirus on them and their organizations, do they demonstrate a high level of loyalty? 
As we can see from Q1 and Q2 (Table 2) more than 70\% of respondents were worried about the impact of coronavirus on themselves and their companies. "Fear for my family and myself" is for $27 \%$ of respondents cause of mental stress and anxiety (Q4). COVID-19 was presented as both a collective and an individual threat. All media were talking about the danger that the pandemic can cause to the lives and economies. Being worried about yourself and your family is the first reaction. The second reaction is connected to the company since people worried about losing their livelihoods because of the low economic activities of the companies during the pandemic. The natural reaction to those threats is the fight and workers accepted all kinds of activities that might be helpful for the organization. It meant more work even though the skills and environment were aggravating factors. But is it the loyalty to the company? Or loyalty to themselves? Or it is a higher level of empathy and social awareness? Employee loyalty is generally viewed as an unambiguously positive attribute at the individual and collective level (Rice et al., 2017, p. 1757). Companies always face problems and dangers in different shapes and forms. The pandemic like the one we face nowadays is just one of them. It seems that workers are personally more involved and more aware of that danger. The loss for the company would be personal as well. In Q5 more than 78\% of respondents selected "the future of their organization" as the biggest challenge and fear. "The ability to support organization" ranked second place and "keeping a regular schedule" the third position (almost $60 \%$ each) in the same question. The answers show dedication to the companies and a positive work attitude. Workers connect their destiny to the destiny of the organization they work for and belong to. Employees' loyalty refers to the extent to which the employees are faithful to the organization (Tseng \& Wu, 2017, p. 683). So being loyal to the company equals being loyal to themselves and their families.

Table 2: Survey - Questions and Responses (n/\%)

Q1. How worried are you about the impact of coronavirus on you?

\begin{tabular}{lrr}
\hline & Count & Percent \\
Extremely worried & 302 & $10.55 \%$ \\
Very worried & 836 & $29.20 \%$ \\
Somewhat worried & 968 & $33.81 \%$ \\
Not so worried & 543 & $18.97 \%$ \\
Not at all worried & 214 & $7.47 \%$
\end{tabular}

Q2. How worried are you about the impact of coronavirus on your company?

\begin{tabular}{lrr}
\hline & Count & Percent \\
Extremely worried & 591 & $20.64 \%$ \\
Very worried & 649 & $22.67 \%$ \\
Somewhat worried & 881 & $30.77 \%$ \\
Not so worried & 521 & $18.20 \%$ \\
Not at all worried & 221 & $7.72 \%$
\end{tabular}

Q3. How easy or difficult is it for you to work effectively these days?

Very easy

Count Percent

Somewhat easy

$454 \quad 15.86 \%$

$303 \quad 10.58 \%$ 
Neither easy nor difficult

411

$14.36 \%$

Somewhat difficult

1201

$41.95 \%$

Very difficult

494

$17.25 \%$

Q4. What has caused you the most mental stress and anxiety in the past few months?

Fear for my family and myself

Count

Percent

Food insecurity

779

$27.20 \%$

Being unprepared for teleworking (skills and resources)

184

$6.43 \%$

Managing work-family conflict

1069

$37.35 \%$

Lack of money

684

$23.89 \%$

147

$5.13 \%$

Q5. What are the TOP FIVE biggest challenges and fears you are currently facing?

The future of my organization

$\begin{array}{rr}\text { Count } & \text { Percent } \\ 2248 & 78.52 \% \\ 1689 & 58.99 \% \\ 1211 & 42.30 \% \\ 1201 & 41.95 \% \\ 1197 & 41.81 \% \\ 1189 & 41.53 \% \\ 1138 & 39.75 \% \\ 1021 & 35.66 \% \\ 1019 & 35.59 \% \\ 977 & 34.13 \% \\ 968 & 33.81 \% \\ 960 & 33.53 \% \\ 951 & 33.22 \% \\ 822 & 28.71 \% \\ 809 & 28.26 \% \\ 788 & 27.52 \%\end{array}$

Supporting the organization to the best of my abilities

Keeping a regular schedule

Childcare

No teleworking programs and instructions

Overworking

Inadequate skills and lack of experience for working remotely

Too many distractions at home

Physical inactivity, stress, and work-related disorders

Inadequate measuring of work performance

$27.52 \%$

Q6. Thinking about your current work from home arrangements, how long is this something you could comfortably maintain?

I do not like this at all

$\begin{array}{rr}\text { Count } & \text { Percent } \\ 146 & 5.10 \% \\ 282 & 9.85 \% \\ 133 & 4.65 \% \\ 461 & 16.10 \% \\ 1841 & 64.30 \%\end{array}$

A few weeks

About a month

$64.30 \%$

Q7. How often would you like the leadership team to communicate how your company will handle business complications due to coronavirus?

$\begin{array}{lrr} & \text { Count } & \text { Percent } \\ \text { Several times a day } & 171 & 5.97 \% \\ \text { Once a day } & 1176 & 41.08 \% \\ \text { A few times a week } & 515 & 17.99 \% \\ \text { Once a week } & 461 & 16.10 \% \\ \text { Only when needed } & 540 & 18.86 \%\end{array}$


Q8. How confident are you in the company's leadership team to make the right decisions to manage through this crisis?

\begin{tabular}{lrr}
\hline & Count & Percent \\
Extremely confident & 689 & $24.07 \%$ \\
Very confident & 1130 & $39.47 \%$ \\
Somewhat confident & 676 & $23.61 \%$ \\
Not so confident & 214 & $7.47 \%$ \\
Not confident at all & 154 & $5.38 \%$ \\
& & \\
Q9. How confident are you that you have the right resources from your company to help \\
support you through this period? & Count & Percent \\
\hline & 485 & $16.94 \%$ \\
Extremely confident & 1145 & $39.99 \%$ \\
Very confident & 632 & $22.07 \%$ \\
Somewhat confident & 377 & $13.17 \%$ \\
Not so confident & 224 & $7.83 \%$ \\
Not confident at all & & \\
Q10. What is your single greatest work-related concern right now? & & \\
\hline How to contribute more to the company results and success & & \\
The competition level of my company & & \\
Company financial stability & & \\
Recruiting problems & & \\
Deadlines & & \\
Work on-line & & \\
Acquiring new skills & & \\
Inability to serve my clients properly & & \\
Social isolation from my coworkers & & \\
\hline
\end{tabular}

RQ2. If workers were unprepared for the pandemic situation and found it difficult to work remotely, do they prefer the traditional way of working compared to teleworking?

The sudden need to change traditional office working style to remote working has revealed that many companies were unprepared for it. More than $60 \%$ of the respondents found it difficult to work remotely (Q3) and 37.35\% indicated that "Being unprepared for teleworking (skills and resources)" caused most stress and anxiety (Q4). However, despite the high level of "overwork", "too many distractions at home", "physical inactivity, stress, and work-related disorders", "inadequate measuring of work performance", "social isolation" and other obstacles they faced, about $43 \%$ of employees would prefer to continue teleworking "forever" while only 5\% say that they do not like teleworking at all (Q6). The possibility to take care of children and other family members (such as disabled parents) is a valuable resource for teleworkers and leads to positive work outcomes: perceived advantages of telework and satisfaction with telework (Nakrošienè et al., 2019:94). In this survey "childcare" with almost 42\% (Q5) was among the five biggest challenges and fears employees face so that the high percentage of those who would permanently like to telework is understandable. Social isolation proved to be a great challenge for the workers as well. However, the social distancing the workers face nowadays is different from the one 
during the regular teleworking. Lockdown itself creates a feeling of anxiety and hopelessness. In regular teleworking, individuals are free to socialize and manage their work schedules themselves. However, in both cases, overworking is common and is also one of the great concerns of our respondents (over 41\%).

\section{RQ3. What is the role of proper leadership and support for teleworking?}

In times of crisis, people tend to trust their leaders more, since trust and hope help them think positive. We deem others trustworthy based on their demonstration of benevolence, integrity, and reliability (Meyer et al., 2017, p. 221). Trust is an axiomatic element of successful leadership (Hasel \& Grover, 2017, p. 849). Proper leadership style influences employee loyalty and organizational commitment. Transformational leadership and building trust can enhance organizational commitment because it is recognized that leaders exhibiting behaviors that are not self-centered, engender employees' trust and respect for the leader, and make employees more proud of their organization membership (Hussain et al., 2018:40).

A very high percentage of employees (over 63\%) are confident in the company's leadership team to make the right decisions to manage through the crisis (Q8). They also appreciate being regularly informed on how the company handles business complications (Q7). However, significantly high patronage of respondents $(34.13 \%)$ expressed their concern on "inadequate measuring of work performance due to remote working" (Q5) and "lack of proper leadership, information, and appreciation" (33.53\%). Fair measurement of work performance and timely feedback is perceived as highly important for employee satisfaction. The positive experiences of the organizational performance appraisal system, especially perceptions of fairness and justice, result in higher levels of work engagement (Memon et al., 2019, p. 1061). A composite measure of remote e-working can provide a holistic view of e-working so that strategies may be developed across a number of key dimensions, rather than specifically relying on only one factor of the e-working experience (Grant et al., 2019, p. 18).

The company provides technology, tools, and support for virtual workers (Makarius \& Larson, 2017, p. 162). Access to the organization's resources as well as the suitability of the working place at home can be considered as an important resource increasing productivity and satisfaction with telework. (Nakrošienè et al., 2019). Over 55\% of respondents are confident that they have the right resources from the company (Q9). Due to high internet traffic in the past period, $28.71 \%$ reported having problems with "Internet connectivity". "Physical workspace" was a great challenge for $28.26 \%$ of respondents, while $27.52 \%$ "lacked tools or information needed to work at home". Comparing to the other items in Q5 these can be seen as relatively low. On the other side, over $41 \%$ indicated a lack of "teleworking programs" and above 33\% had "hard communication with coworkers" (Q5). Organizations should redefine their human resources development policies. Almost $40 \%$ of workers feel that they do not have "adequate skills and lack experience for working remotely" (Q5). The pressure of working from home and "managing work-family conflict", overworking", "too many distractions at home", "physical inactivity, stress, and work-related disorders" ranging from $24 \%$ to $41 \%$ are 
factors that can be avoided with proper training. Although considered as a good mechanism to facilitate work-life balance, if not managed properly teleworking may add additional weight on work-family conflict. Even if working from home reduces time spent commuting and may help a person better manage household and care tasks, it seems to be conducive to more intrusions on family concerns (Ferri et al., 2018, p. 914). Therefore, it is important to train employees to be able to enjoy both private and professional life.

\section{RQ4. Does teleworking under lockdown differ to a great extent from traditional} teleworking?

How different is the lockdown teleworking from the traditional one? During the lockdown, workers face different problems such as increased fear for personal and family safety, company stability, and professional work-related issues as we have seen in the previous comments. Comparing to traditional teleworking, working remotely under lockdown causes different "physical inactivity, stress, and work-related disorders" as reported by $35.59 \%$ of respondents (Q5). Workers need to do more work in less time, and therefore may risk not being able to handle the work demands leading to burnout (Semeijn et al., 2019, p. 388). Besides, the pressure of "overworking" and "social isolation" as well as a very high level of stress may lead to burnout. In such situations, professional support or treatment is highly recommended.

\section{Conclusion}

It is a good sign for companies to find out that employees are even more loyal in times of crisis. What needs to be done in the future by companies is to develop appropriate teleworking programs and instructions and to enable teleworking for jobs that can be organized on-line. It would lead to higher job satisfaction and company loyalty. Employees do need proper leadership and support for teleworking. Teleworking cannot be successful if no support is provided including regular training and even psychological support in case of burnout and stress.

\section{References}

Amiruddin, A. (2019). Mediating effect of work stress on the influence of time pressure, work-family conflict and role ambiguity on audit quality reduction behavior. International Journal of Law and Management, 61(2), 434-454. Doi: https://doi.org/10.1108/IJLMA-092017-0223

De Cuyper, N., Schreurs, B., De Witte, H., \& Selenko, E. (2020). Impact of job insecurity on job performance introduction. Career Development International, 25(3), 221-228. Doi: https://doi.org/10.1108/CDI-06-2020-332

Delpechitre, D., Black, H., \& Farrish, J. (2019). The dark side of technology: examining the impact of technology overload on salespeople. Journal of Business \& Industrial Marketing, 34(2), 317-337. Doi: https://doi.org/10.1108/JBIM-03-2017-0057 
Eppler, J. M., \& Mengis, J. (2004). The concept of information overload: A review of literature from organization science, accounting, marketing, MIS, and related disciplines. Information Society, 20(5), 325-344. Doi: https://doi.org/10.1080/01972240490507974

Erceg, V., \& Zoranović, T. (2020). Required competencies for successful digital transformation. Ekonomika, 66(3), 47-54.Doi: https://doi.org/10.5937/ekonomika2003047E

EUROSTAT. (2020). How usual is it to work from home? Retrieved from EUROSTAT: https://ec.europa.eu/eurostat/en/web/products-eurostat-news/-/DDN-20200424-1 (accessed on May 29 2020).

Ferri, L., Pedrini, M., \& Riva, E. (2018). The impact of different supports on work-family conflict. Employee Relations, 40(5), 903-920. Doi: https://doi.org/10.1108/ER-09-2017$\underline{0211}$

Gajendran, R. S., \& Harrison, D. A. (2007). The good, the bad, and the unknown about telecommuting: Meta-analysis of psychological mediators and individual consequences. Journal of Applied Psychology, 92(6), 1524-1541. Doi: https://doi.org/10.1037/00219010.92.6.1524

Golden, T. D., \& Veiga, J. F. (2006). The Impact of Extent of Telecommuting on Job Satisfaction: Resolving Inconsistent Findings. Journal of Management, 31(2), 301-318. Doi: https://doi.org/10.1177/0149206304271768

Graham, B., \& Cascio, W. (2018). The employer-branding journey: Its relationship with cross-cultural branding, brand reputation, and brand repair. Management Research, 16(4), 363-379. Doi: https://doi.org/10.1108/MRJIAM-09-2017-0779

Grant, C., Wallace, L. M., Spurgeon, P. C., Tramontano, C., \& Charalampous, M. (2019). Construction and initial validation of the E-Work Life Scale to measure remote e-working. Employee Relations, 41(1), 16-33. Doi: https://doi.org/10.1108/ER-09-2017-0229

Hasel, M., \& Grover, S. (2017). An integrative model of trust and leadership. Leadership \& Organization Development Journal, 38(6), 849-867. Doi: https://doi.org/10.1108/LODJ-12$\underline{2015-0293}$

Hussain, S., Shujahat, M., Malik, M. I., Iqbal, S., \& Mir, F. N. (2018). Contradictory results on the mediating roles of two dimensions of trust between transformational leadership and employee outcomes. Journal of Organizational Effectiveness: People and Performance, 5(1), 39-63. Doi: https://doi.org/10.1108/JOEPP-11-2016-0063

Jabagi, N., Croteau, A. M., Audebrand, L., \& Marsan, J. (2019). Gig-workers' motivation: thinking beyond carrots and sticks. Journal of Managerial Psychology, 34(4), 192-213. Doi: https://doi.org/10.1108/JMP-06-2018-0255

Karr-Wisniewski, P., \& Lu, Y. (2010). 'When More is Too Much: Operationalizing Technology Overload and Exploring its Impact on Knowledge Worker Productivity'. Computers in Human Behavior, 26(5), 1061-1072. Doi: https://doi.org/10.1016/j.chb.2010.03.008

Kossek, E., Thompson, R. J., \& Lautsch, B. (2015). Balanced workplace flexibility: avoiding the traps. California Management Review, 57(4), 5-25. Doi: https://doi.org/10.1525/cmr.2015.57.4.5 
Kowalski, B. K., \& Swanson, J. (2005). Critical success factors in developing teleworking programs. Benchmarking: An International Journal, 12(3), 236-249. Doi: https://doi.org/10.1108/14635770510600357

Lajšić, H. (2019). 'Strategic human resources management and business intelligence systems in the purpose of social and economic development'. Časopis za ekonomiju $i$ tržišne komunikacije, 9(1), 53-68. Doi: https://doi.org/10.7251/EMC1901053L

Liu, C., Ready, D., Roman, A., Van Wart, M., Wang, X., McCarthy, A., \& Kim, S. (2018). E-leadership: an empirical study of organizational leaders' virtual communication adoption. Leadership \& Organization Development Journal, 39(7), 826-843. Doi: https://doi.org/10.1108/LODJ-10-2017-0297

Makarius, E., \& Larson, B. (2017). Changing the Perspective of Virtual Work: Building Virtual Intelligence at the Individual Level. The Academy of Management Perspectives, 31(2), 159-178. Doi: https://doi.org/10.5465/amp.2014.0120

Memon, M., Salleh, R., Mirza, M. Z., Cheah, J. H., Ting, H., \& Ahmad, M. (2019). Performance appraisal satisfaction and turnover intention: The mediating role of work engagement. Management Decision, 58(6), 1053-1066. Doi: https://doi.org/10.1108/MD$\underline{06-2018-0685}$

Meyer, F., Le Fevre, D. M., \& Robinson, V. M. (2017). How leaders communicate their vulnerability: implications for trust building. International Journal of Educational Management, 31(2), 221-235. Doi: https://doi.org/10.1108/IJEM-11-2015-0150

Nakrošienė, A., Bučiūnienè, I., \& Goštautaitė, B. (2019). Working from home: characteristics and outcomes of telework. International Journal of Manpower, 40(1), 87101. Doi: https://doi.org/10.1108/IJM-07-2017-0172

Pigini, C., \& Staffolani, S. (2019). Teleworkers in Italy: who are they? Do they make more?. International Journal of Manpower, 40(2), 265-285. Doi: https://doi.org/10.1108/IJM-07-2017-0154

Pindek, S., Howard, D. J., Krajcevska, A., \& Spector, P. (2019). 'Organizational constraints and performance: an indirect effects model. Journal of Managerial Psychology, 34(2), 7995. Doi: https://doi.org/10.1108/JMP-03-2018-0122

Rice, B., Knox, K., Rice, J., Martin, N., Fieger, P., \& Fitzgerald, A. (2017). Loyal employees in difficult settings: The compounding effects of inter-professional dysfunction and employee loyalty on job tension. Personnel Review, 46(8), 1755-1769. Doi: https://doi.org/10.1108/PR-05-2016-0124

Semeijn, J., Van Ruysseveldt, J., Vonk, G., \& van Vuuren, T. (2019). In flight again with wings that were once broken; effects of post-traumatic growth and personal resources on burnout recovery. International Journal of Workplace Health Management, 12(5), 387-403. Doi: https://doi.org/10.1108/IJWHM-01-2019-0006

Solís, M. (2017). Moderators of telework effects on the work-family conflict and on worker performance. European Journal of Management and Business Economics, 26(1), 21-34. Doi: https://doi.org/10.1108/EJMBE-07-2017-002 
Stich, J. F., Tarafdar, M., \& Cooper, C. (2018). Electronic communication in the workplace: boon or bane?. Journal of Organizational Effectiveness: People and Performance, 5(1), 98-106. Doi: https://doi.org/10.1108/JOEPP-05-2017-0046

Stich, J.-F., Tarafdar, M., Stacey, P., \& Cooper, C. (2019). E-mail load, workload stress and desired e-mail load: a cybernetic approach. Information Technology \& People, 32(2), 430452. Doi: https://doi.org/10.1108/ITP-10-2017-0321

Suh, A., \& Lee, J. (2017). Understanding teleworkers' technostress and its influence on job satisfaction. Internet Research, 27(1), 140-159. Doi: https://doi.org/10.1108/IntR-06-2015$\underline{0181}$

Tseng, L. M., \& Wu, J. Y. (2017). How can financial organizations improve employee loyalty? The effects of ethical leadership, psychological contract fulfillment and organizational identification. Leadership \& Organization Development Journal, 38(5), 679698. Doi: https://doi.org/10.1108/LODJ-07-2015-0142

Wang, W., Albert, L., \& Sun, Q. (2020). Employee isolation and telecommuter organizational commitment. Employee Relations, 42(3), 609-625. Doi: https://doi.org/10.1108/ER-06-2019-0246

Zatzick, C., Deery, S., \& R., I. (2015). Understanding the Determinants of Who Gets Laid Off: Does Affective Organizational Commitment Matter?. Human Resource Management, 54(6), 877-891. Doi: https://doi.org/10.1002/hrm.21641 